\title{
Reinventing Pedagogy of the Oppressed: Contemporary critical perspectives
}

\author{
James D. Kirylo (Ed.). Bloomsbury Academic, London, 2020, 260 pp. \\ ISBN 978-1-3501-1718-1 (hbk), ISBN 978-1-3501-1717-4 (pbk), ISBN \\ 978-1-3501-1720-4 (ePUB), ISBN 978-1-3501-1719-8 (ePDF)
}

\section{Shahrzad Mojab ${ }^{1}$}

Published online: 7 November 2020

(c) UNESCO Institute for Lifelong Learning and Springer Nature B.V. 2020

It is a prodigious task to reinvent Pedagogy of the Oppressed, ${ }^{1}$ one of the most influential texts in the discipline of education, written more than five decades ago by Brazilian pedagogue and social justice activist, Paulo Freire. In Reinventing Pedagogy of the Oppressed: Contemporary Perspectives, contributors engage with the "deep social justice thread" of Freire's ontological and epistemological perspective and discuss a range of subjects such as "theology, technology, ecology, school reform, pedagogy, curriculum, leadership, politics, gender, sexual orientation, race, culture, ethnicity, psychology, and communication" (pp. 4-5).

This interdisciplinary anthology is thematically organised into five parts: I "The criticality of teacher preparation", II "Pedagogy and practice", III "The intersection of Paulo Freire and Myles Horton, Martin Luther King, Jr., and Simone de Beauvoir", IV "Policy, the environment, and liberation theology" and V "Reflections, experiences, and consideration." Thirty-three established and emerging scholars have contributed to this volume. They (re)read and (re)analyse Freire in diverse geographical sites and from distinct disciplinary approaches. In a brief Foreword to the volume, titled "On the Road to Social Justice: Reinventing Paulo Freire", Ira Shor, a prominent exponent of critical pedagogy and former collaborator with Paulo Freire, precisely summarises the content by stating that "readers will encounter a panorama of reinvention, not standardization, which is what Paulo called for, a praxis ${ }^{2}$ of adaptive local agency - action/reflection/action emerging for and from specific sites" (p. xi).

\footnotetext{
${ }^{1}$ Freire, P. (1970). Pedagogy of the oppressed. New York: Continuum.

${ }^{2}$ In the context of Paulo Freire's work, the term praxis refers to "reflection and action directed at the structures to be transformed" (Freire 1970, p. 126).
}

Shahrzad Mojab

shahrzad.mojab@utoronto.ca

1 Ontario Institute for Studies in Education, University of Toronto, Toronto, ON, Canada 
Reading this volume under the exceptional global circumstances of our time, when the COVID-19 pandemic has exposed the profound racial, patriarchal and class scars of colonialism and capitalist imperialism, requires the reader to engage in deep contemplation to reinvent Freire's universal human ethics of passion, hope and love. For instance, one cannot help but wonder how Freire's return to Brazil would look today, given its current condition as a populous country in the grips of a neoliberal authoritarian political order denying any scientific evidence of the pandemic. In Chapter 19, titled "An Eye-Witness Account of Freire's Return Back to Brazil after the Exile: Personal Reflections on Fighting Oppression" Nelio Bizzo, a prominent scholar and former member of the National Council of Education of the Brazilian Ministry of Education, writes that "[i]n a very real way, it appears Brazil is going back in time, with many idolizing authoritarianism and not realizing how oppression works and how democratic spaces erode into a place of non-existence. There is no doubt it is time to welcome Paulo Freire again in Brazil" (p. 220).

Undoubtedly, it is time to (re)turn to, (re)new and (re)invent Freire's theory and practice on pedagogy, consciousness, and revolutionary social transformation. The chapters in this collection try to realise this task by taking up discussions of teacher education in South Africa (Chapter 1) and in the United States (in Detroit, Chapter 3); navigating critical race consciousness and consciousness-raising in early childhood education (Chapter 2), in literature and religious studies (Chapter 5), and in neoliberal universities (Chapter 17); fostering a Freirean dialogical approach in prison classrooms (Chapter 4 ) and in K-12 classrooms (Chapter 9); ${ }^{3}$ focusing on the Freirean notion of "Cultural Circles" in K-12 (Chapter 7); ${ }^{4}$ theorising surveillance capitalism in digital technology (Chapter 6); reconsidering Freire's emancipatory project of a "Prophetic Church" in a "postdigital reality" (Chapter 16); historicising community organising strategies, social justice activism, and fostering Freirean hope and liberation (Chapters 10,11, 12, and Chapter 18, which focuses on lesbian, gay, bisexual, transgender and queer [LGBTQ+] educators); ethics of relationality inspired by Indigenous worldviews (Chapter 14) and ecological discourse (Chapter 15). The last two chapters (Chapter 19 and 20) in particular get closer to the philosophy and pedagogy of Freire, but as the editor, James D. Kirylo, writes, all "chapter contributors uniquely reinvented Paulo Freire in these contemporary times, a reinvention that is threaded with the task to build a more just, more equal, more humane, and more hopeful world" (p. 11).

Antonia Darder, in her persuasive Afterword, titled "Paulo Freire Fifty Years Later", concludes: "It is important then to begin a discussion about Paulo's legacy here, in that often, it has been precisely Freire's revolutionary critique of capitalism and the link of schooling to class struggle, that have been stripped away, resulting in watered down and diluted versions of his ideas" (p. 233). Wayne Au, a Marxist educator, comments that "Freire's liberatory pedagogy is a part of the Marxist,

\footnotetext{
${ }^{3} \mathrm{~K}-12$ refers to education spanning Kindergarten to Grade 12 (the last year of secondary/high school in the United States).

${ }^{4}$ Freirean cultural circles are spaces and pedagogical approachs to facilitate dialogue and learning about larger social issues of democracy, justice, poverty and inequality.
} 
dialectical materialist tradition, and as such, it is fundamentally anti-capitalist and has the goal of upending capitalist relations. This is why Freire was jailed and exiled, why Freirean pedagogy is so powerful for teaching and organizing, and why right-wing conservatives remain bitter and fearful about his influence in US education" (Au 2018, p. 178). ${ }^{5}$

There is a conspicuous absence of Paula Allman's seminal works on critical education, revolutionary social transformation, and revolutionary consciousness (Allman 1999, 2001). ${ }^{6}$ Allman argues that "Gramsci and Freire contribute something new to Marx's thought by discussing in detail how socialist educators, or political activists, or any other cultural workers for social transformation should work with people prior to the moment of revolution" (Allman 1999, p. 118, emphasis in original). She urges us not to use their ideas "... to dictate strategies but to inform and guide the development of a critical/revolutionary praxis based on a dialectical understanding of our present conditions. Surely Gramsci and Freire, or any other critical (dialectical) thinker, would never advise otherwise" (ibid., p. 123). This perspective has not been fully developed by the diverse cases presented in this collection.

Reinventing Pedagogy of the Oppressed: Contemporary Critical Perspectives is written in an accessible manner and is empirically rich; however, we should persist in pushing the boundaries of criticality in Freire's ontology, epistemology and ethics when engaging in revolutionary praxis.

\footnotetext{
${ }^{5} \mathrm{Au}$, W. (2018). A Marxist education: Learning to change the world. Chicago, IL:Haymarket Books. See Chapter 6, "Teaching to change the world: The Marxist, Dialectical Materialist pedagogy of Paulo Freire" (pp. 153-178).

${ }^{6}$ Allman, P. (1999). Revolutionary social transformation: Democratic hopes, political possibilities and critical education. Westport, CT: Bergin \& Garvey. See Chapter 6, "Freirean critical education in an unlikely context" (pp. 187-216), and Chapter 5, "Education and social transformation: The ideas of Freire and Gramsci" (pp. 85-125).

Allman, P. (2001). Critical education against global capitalism: Karl Marx and revolutionary critical education. Westport, CT: Bergin \& Garvey.
} 